\section{Posttransplant Growth of Container-grown Wild Coffee, Copperleaf, and Orange Jasmine Is Affected by Irrigation Frequency}

\author{
Kimberly A. Moore ${ }^{1,7}$, Amy L. Shober ${ }^{2}$, Edward F. Gilman ${ }^{3}$, \\ Christine Wiese ${ }^{4}$, S. Michelle Scheiber ${ }^{5}$, Maria Paz $^{4}$, \\ and Meghan M. Brennan ${ }^{6}$
}

AdDitional Index words. landscape management, Psychotria nervosa, Acalypha wilkesiana, Murraya paniculata

SUMMARY. The survival of shrubs planted into the landscape depends on sufficient irrigation during the establishment period. Few studies have investigated the effect of irrigation frequency on the posttransplant growth of landscape shrubs. We conducted two studies in U.S. Department of Agriculture hardiness zone $10 \mathrm{~b}$ over a 2 -year period in which we compared canopy growth index (GI), root extension to canopy spread ratio, canopy dry weight, and root dry weight of shrubs irrigated at different frequencies. In the first experiment, wild coffee (Psychotria nervosa) and 'Lakeview' orange jasmine (Murraya paniculata) shrubs were planted in Sept. 2004, Dec. 2004, Mar. 2005, and June 2005 and irrigated for 28 weeks after planting (WAP) every 2, 4 , or 8 days with $3 \mathrm{~L}$ of water per irrigation event. In the second experiment, 'Macafeeana' copperleaf (Acalypha wilkesiana) and orange jasmine shrubs were planted in Sept. 2005, Dec. 2005, Mar. 2006, and June 2006 and irrigated for 28 WAP every 1, 2, or 4 days with 3 L of water per irrigation event. Canopy GI and root extension to canopy spread ratio were determined at 28, 52, and $104 \mathrm{WAP}$. The entire canopy and roots were harvested 52 and 104 WAP to determine dry weight. In Expt. 1 , wild coffee and orange jasmine plants irrigated every 2 days had greater GI than plants irrigated every 8 days at 28 WAP, but GI was not different at 52 or 104 WAP. Canopy dry weight at 52 WAP was greater for plants irrigated every 2 days than every 8 days, but there was no difference at 104 WAP. There was no difference in wild coffee or orange jasmine root dry weight or root extension to canopy spread ratio among the irrigation frequencies. In Expt. 2, there were no differences in GI, canopy dry weight, root dry weight, or root extension to canopy spread ratio of copperleaf or orange jasmine irrigated everyday compared with plants irrigated every 2 or 4 days. From the data collected in these studies, it appears that irrigating wild coffee or orange jasmine every 8 days during the first 28 WAP limited canopy growth but not root development. However, after $52 \mathrm{WAP}$, rainfall events appeared to be sufficient to eliminate any initial effects from irrigation frequency. Our data suggest that wild coffee, orange jasmine, and copperleaf from 3-gal containers can be successfully established in the landscape when irrigated with $3 \mathrm{~L}$ of water every 4 days for the first 28 WAP.

$\mathrm{R}$ apid urban population growth, droughts, wasteful irrigation use practices, and other factors have led to mandatory water restrictions in parts of the United States. Mandatory irrigation restrictions in Florida typically allow daily irrigation for $60 \mathrm{~d}$ (or less) for establishment of newly installed plant material, regardless of plant type (e.g., turfgrass, shrubs, trees, or bedding plants), and then irrigation is ended (South Florida Water Management District, 2008; Southwest Florida Water Management District, 2008; St. Johns River Water Management District, 2008). These restrictions are imposed despite suggestions that plants installed into the landscape from 3-gal nursery containers require 6 to 12 months to become fully established (Trenholm et al., 2002). are irrigated one to several times per day in the nursery. As a result, plants can become stressed when not properly irrigated in the landscape during establishment because their roots are
Most container-grown shrubs

confined to a small root ball developed in the container (Costello and Paul, 1975). Irrigation is required until the plants develop sufficient root systems in the landscape soil to allow the plant to compensate for losses resulting from evapotranspiration (Barnett, 1986; Gilman et al., 1996; Montague et al., 2000). Insufficient irrigation immediately after planting may result in poor growth or plant death (Geisler and Ferree, 1984a; Harris and Gilman, 1993).

Many studies have reported increased growth in response to increased irrigation frequency during establishment (Barnett, 1986; Marshall and Gilman, 1998; Stabler and Martin, 2000). It appears that irrigation frequency may have a greater impact on woody plant establishment than irrigation volume (Gilman et al., 1996; Renquist, 1987). Currently, the majority of studies on the impact of irrigation frequency during establishment have been conducted on trees. There have been few studies that investigated the effect of irrigation frequency on growth of landscape shrubs during and after establishment. Furthermore, no studies have investigated the effect of irrigation frequency on shrubs grown in the unique environment and soils that characterize southern Florida. The objective of this study was to compare the effects of irrigation frequency during establishment on the growth and quality of wild coffee, orange jasmine, and copperleaf planted into the landscape from 3-gal containers.

\section{Materials and methods}

Wild coffee, copperleaf, and orange jasmine obtained from commercial nurseries in 3-gal smoothsided pots were planted at the University of Florida, Fort Lauderdale

\begin{tabular}{llll}
\hline $\begin{array}{l}\text { Units } \\
\text { To convert U.S. to SI, } \\
\text { multiply by }\end{array}$ & U.S. unit & SI unit & $\begin{array}{l}\text { To convert SI to U.S., } \\
\text { multiply by }\end{array}$ \\
\hline 0.3048 & $\mathrm{ft}$ & $\mathrm{m}$ & 3.2808 \\
0.0929 & $\mathrm{ft}^{2}$ & $\mathrm{~m}^{2}$ & 10.7639 \\
0.0283 & $\mathrm{ft}^{3}$ & $\mathrm{~m}^{3}$ & 35.3147 \\
3.7854 & gal & $\mathrm{L}$ & 0.2642 \\
2.54 & inch $(\mathrm{es})$ & $\mathrm{cm}$ & 0.3937 \\
25.4 & inch $(\mathrm{es})$ & $\mathrm{mm}$ & 0.0394 \\
48.8243 & $\mathrm{lb} / 1000 \mathrm{ft}^{2}$ & $\mathrm{~kg} \cdot \mathrm{ha}^{-1}$ & 0.0205 \\
1.1209 & $\mathrm{lb} / \mathrm{acre}$ & $\mathrm{kg} \cdot \mathrm{ha}^{-1}$ & 0.8922 \\
1 & $\mathrm{meq} / 100 \mathrm{~g}$ & $\mathrm{cmol} \cdot \mathrm{kg}^{-1}$ & 1 \\
1 & $\mathrm{mmho} / \mathrm{cm}^{\mathrm{O}}$ & $\mathrm{dS} \cdot \mathrm{m}^{-1}$ & 1 \\
28.3495 & $\mathrm{Oz}$ & $\mathrm{g}$ & 0.0353 \\
1 & $\mathrm{ppm}$ & $\mathrm{mg} \cdot \mathrm{kg}^{-1}$ & 1 \\
$\left({ }^{\circ} \mathrm{F}-32\right) \div 1.8$ & ${ }^{\circ} \mathrm{F}$ & ${ }^{\circ} \mathrm{C}$ & $\left(1.8 \times{ }^{\circ} \mathrm{C}\right)+32$ \\
& & &
\end{tabular}


Research and Education Center, Fort Lauderdale (lat. 26 ${ }^{\circ} 5^{\prime} 6.36^{\prime \prime} \mathrm{N}$, long. $80^{\circ} 14^{\prime} 25.39^{\prime \prime}$ W) located in U.S. Department of Agriculture hardiness zone 10b (Cathey, 1990). The soil (Margate fine sand, siliceous, hyperthermic Mollic Psammaquents) had $2.2 \%$ organic matter content, $88 \mathrm{lb} /$ acre estimated nitrogen release, 52 ppm weak Bray phosphorus, 160 ppm strong Bray phosphorus, 14 ppm potassium, 27 ppm magnesium, 1870 ppm calcium, $\mathrm{pH} 7.1$, and 9.6 meq/100 g cation exchange capacity.

All shrubs were planted within 1 week of pickup and were in similar states of being root-bound. Differences in initial shrub size were considered by including initial shrub size as a covariate in the analysis.

Wild coffee and orange jasmine shrubs were planted in Sept. 2004, Dec. 2004, Mar. 2005, and June 2005 and irrigated every 2, 4, or $8 \mathrm{~d}$ (Expt. 1). Copperleaf and orange jasmine shrubs were planted in Sept. 2005, Dec. 2005, Mar. 2006, and June 2006 and irrigated every 1, 2, or $4 \mathrm{~d}$ (Expt. 2). As a result of poor growth performance, wild coffee, a low drought-tolerant plant, was replaced in Expt. 2 with copperleaf, which is also classified as a low drought-tolerant plant. Orange jasmine was used in both experiments as a representative of a high drought-tolerant plant. Furthermore, as a result of poor plant performance of shrubs irrigated every $8 \mathrm{~d}$ in Expt. 1, this treatment was replaced in Expt. 2 with irrigating every $1 \mathrm{~d}$.

The work was supported by the Florida Agricultural Experiment Station, the Florida Department of Agriculture and Consumer Services, the South Florida Water Management District, the Southwest Florida Water Management District, the St. Johns River Water Management District, and the Florida Nursery, Growers and Landscape Association.

${ }^{1}$ Associate Professor University of Florida, IFAS, Environmental Horticulture Department, FLREC 3205 College Avenue, Ft. Lauderdale FL 33314

${ }^{2}$ Assistant Professor, University of Florida, IFAS, Center for Landscape Conservation and Ecology, Soil and Water Science Department, Gulf Coast REC, 14625 CR 672, Wimauma, FL 33598

${ }^{3}$ Professor, University of Florida, IFAS, Environmental Horticulture Department, 100 Mehrhof Hall, P.O. Box 110675, Gainesville, FL 32611

${ }^{4}$ Biological Scientist, University of Florida, IFAS, Environmental Horticulture Department, $100 \mathrm{Mehr}$ hof Hall, P.O. Box 110675, Gainesville, FL 32611

${ }^{5}$ Assistant Professor, University of Florida, IFAS, Mid-Florida REC, 2725 Binion Road, Apopka, FL 32703

${ }^{6}$ Statistical Research Coordinator, University of Florida, IFAS, Department of Statistics, 418 McCarty Hall C, P.O. Box 110339, Gainesville, FL 32611-0339

${ }^{7}$ Corresponding author. E-mail: klock@ufl.edu.
Six single-plant replicates of wild coffee, copperleaf, and orange jasmine shrubs were randomly interplanted for each irrigation frequency (three) and planting date (four) combination. Each treatment combination was blocked by six rows that were oriented north to south. Shrubs were planted according to University of FloridaInstitute of Food and Agricultural Sciences practices (Gilman et al., 2009) and maintained in the field for 104 weeks after planting (WAP). All shrubs were planted on 12-inch centers with the top of the root ball even with the landscape soil surface; root balls were left undisturbed at planting. Immediately after planting, coarse (pieces 3 to 4 inches long) woody yard waste mulch (Safari Tree Professionals, Davie, FL) was applied at a 3 -inch thickness in 5 -ft-wide rows with the shrubs in the middle of the row. No mulch was placed on top of the root ball. Bahiagrass (Paspalum notatum) was maintained in 4 - $\mathrm{ft}$-wide strips between planting rows. Shrubs were sufficiently watered at planting and irrigation treatments started the day after planting.

Each shrub was irrigated with $3 \mathrm{~L}$ of water per irrigation event with three bubbler emitters (Shrubbler 360; Antelco, Longwood, FL) regardless of rainfall. The source of water was a pond located at the site and the water had an $0.36 \mathrm{dS} \cdot \mathrm{m}^{-1}$ electrical conductivity, 94 ppm calcium carbonate total alkalinity, 0.6 ppm nitrate-nitrogen, 28 ppm calcium, 6 ppm magnesium, and 22 ppm sodium. Each emitter was mounted 4 inches aboveground level with one emitter located on the east and west side of each plant, 6 inches from the outside of the root ball; the third emitter was positioned on the root ball. Each irrigation frequency was controlled as a separate zone using a valve controller (Model SVC; Hunter Industries, San Marcos, CA). Irrigation began at $0800 \mathrm{HR}$ and was completed by 0830 HR. Flow meters (Model C700; AMCO, Ocala, FL) were installed for each irrigation treatment to confirm water volume being applied to each row. Irrigation was turned off for all plants at 28 WAP based on data collected from previous experiments indicating that shrubs were nearly established 16 to 28 WAP (Scheiber et al., 2007). After irrigation was ended, supplemental irrigation (3 L per plant) was supplied periodically to all shrubs for that planting date when signs of severe water stress (wilting, leaf drop, yellowing, or browning leaves) were apparent and rainfall was less than $6 \mathrm{~mm}$ in any 24-h period consecutively for $32 \mathrm{~d}$.

Monthly rainfall data were collected by the Florida Automated Weather Network (University of Florida, 2008) located within $50 \mathrm{~m}$ of the planting site. Cumulative rainfall amounts from 0 to 28,29 to 52 , and 53 to 104 WAP were determined by summing the monthly rainfall totals. Historical averages for monthly rainfall were obtained from the $\mathrm{Na}$ tional Oceanic and Atmospheric Administration [National Oceanic and Atmospheric Administration (NOAA), 2002].

All plots were fertilized according to University of Florida-Institute of Food and Agricultural Sciences best management practices (Trenholm et al., 2002). Controlled-release fertilizer was applied every 3 months beginning $30 \mathrm{~d}$ after planting at an nitrogen rate of $1 \mathrm{lb} / 1000 \mathrm{ft}^{2}$ by broadcasting 12N-0.9P-11.6K (Southern Ornamental and Landscape Fertilizer; LESCO, Cleveland, $\mathrm{OH}$ ) uniformly over a $9-\mathrm{ft}^{2}$ area around each shrub. Weeds were controlled by hand or with periodic applications of glyphosate (Roundup; Monsanto, St. Louis, MO). Shrubs were not pruned during the study.

To evaluate shrub growth, canopy height and width were measured at planting and at 28, 52, and 104 WAP. Measurements of canopy height, greatest canopy width (Width 1 ), and width perpendicular to the greatest width (Width 2 ) were used to calculate canopy growth index in cubic meters $(\mathrm{GI}=$ height $\times$ Width $1 \times$ Width 2). Measurements were taken on six single-plant replicates per irrigation frequency treatment and planting date. In addition, plant density and dieback (quality) were visually rated on all plants on a scale of 1 (dead) to 9 (very good, dense canopy, no dieback) at 28, 52, and 104 WAP.

Maximum root extension was measured at 28, 52, and 104 WAP on three random single-plant replicates per irrigation treatment and planting date by excavating the longest root on the east and west side of the plant and measuring its length from the trunk. Roots were excavated by gently removing the mulch layer 
from a section of soil $\approx 30 \mathrm{~cm}$ wide and $100 \mathrm{~cm}$ from the base of the plant and digging toward the plant until the outermost roots were identified. Root extension to canopy spread radius ratios were calculated by dividing the mean of the root extension by the canopy spread where mean canopy spread (in centimeters) $=1 / 2 \times$ (Width $1+$ Width 2).

Canopy dry weight and root system dry weight were measured at 52 and 104 WAP. Three randomly selected single-plant replicates were harvested per irrigation treatment and planting date at 52 and 104 WAP. The entire aboveground canopy was harvested and dried to a constant weight at $105{ }^{\circ} \mathrm{C}$. Two wedge-shaped sections of soil containing $\approx \mathrm{l} / 8$ of roots extending beyond the trunk were harvested from each shrub where the canopy was removed. Soil material was removed using a sieve and root material was sorted, removed, and then dried at $105^{\circ} \mathrm{C}$ for $4 \mathrm{~d}$ to determine the dry weight of roots. Total root system dry weight was calculated by: root weight (in grams) $=$ dry root weight harvested $\times 8$.

Data Analysis. The experiment was designed as a randomized complete block design with three irrigation frequencies applied randomly to six single-plant replicates of each species within each planting date. Irrigation frequency was the only fixed effect analyzed. Location in the field was randomly assigned for each planting date and planting date was included in the analysis as a random effect. Growth index, root extension, and root extension to canopy spread ratio were analyzed separately for each plant species and for each data collection date $(28,52$, and 104 WAP) to investigate differences among the irrigation frequencies (the fixed effect) using the PROC MIXED procedure in SAS (Version 9.1; SAS Institute, Cary, NC). For analysis of GI, initial GI at 0 WAP was included in the model as a covariate to account for variation in initial plant size at different planting dates. Plant quality (density and dieback) data were analyzed using the PROC GLMIMMIX program in SAS (Version 9.1) using the multinomial distribution and the cumulative logit link function. Differences in canopy and root dry weight among the irrigation frequencies were analyzed separately by species for 52 and 104 WAP using the PROC MIXED procedure in SAS (Version 9.1). All pairwise comparisons were completed using the Tukey least squares means test with a significance level of $\alpha=0.05$.

\section{Results and discussion}

Plant Quality. There were no significant differences in plant quality in wild coffee, orange jasmine, or copperleaf in either experiment as a result of irrigation frequency (data not shown). Paine et al. (1992) also reported no significant differences in visual appearance among four irrigation frequency treatments for carmel creeper (Ceanoths griseus var. horizontalis), coffeeberry (Rhamnus californ$i c a)$, and photinia (Photinia $\times$ fraseri). Fitzpatrick and Burch (1986) initially observed differences in orange jasmine quality resulting from different irrigation volumes after planting into the same field site as the current studies, but after 3 months in the field, there was no difference in quality. They speculated that this was likely the result of the influence of rainfall events because they recorded a cumulative total of $59.37 \mathrm{~cm}$ of rain during their 3-month field study. It is possible that rainfall events during the course of Expts. 1 and 2 similarly negated the effects of irrigation frequency of shrub quality (Fig. 1). For both experiments and all planting dates, over $150 \mathrm{~cm}$ rain fell from 0 to $52 \mathrm{WAP}$ and over $300 \mathrm{~cm}$ of rain from 0 to 104 WAP (Fig. 1). The rainfall values recorded during these experiments are close to the historical average rainfall value of $184 \mathrm{~cm}$ per year for Fort Lauderdale (NOAA, 2002).

For all irrigation treatments and planting dates in Expt. 1, wild coffee quality ratings (density, dieback) ranged from 4 to 5 on a scale of 1 to 9 (9 was considered optimum). Poor quality performance in Expt. 1 of wild coffee was attributed to growing it under full sun conditions. Wild coffee has been reported to perform best as an understory shrub in partial to full shade (Broschat and Meerow, 1996; Gilman, 1996). When wild coffee plants are grown in full sun, they require a lot of water (Gilman, 1996). Wild coffee was included in Expt. 1 as a representative species of a low drought-tolerant plant and as a contrast to orange jasmine, which is classified as a high drought-tolerant plant in Florida (Broschat and Meerow, 1996; Gilman, 1996). As a result of poor performance, wild coffee was replaced in Expt. 2 with copperleaf, which also is classified as a low drought-tolerant plant in Florida.

CANOPY AND ROOT GROWTH. In Expt. 1, wild coffee and orange jasmine GI at 28 WAP was greater for plants irrigated every $2 \mathrm{~d}$ than every 8 d (Fig. 2). Although there were no differences in wild coffee or orange jasmine GI at 52 or 104 WAP, canopy dry weight at 52 WAP was greater for plants irrigated every $2 \mathrm{~d}$ than every $8 \mathrm{~d}$ (Table 1 ). We suspect that irrigation frequency during the first 28

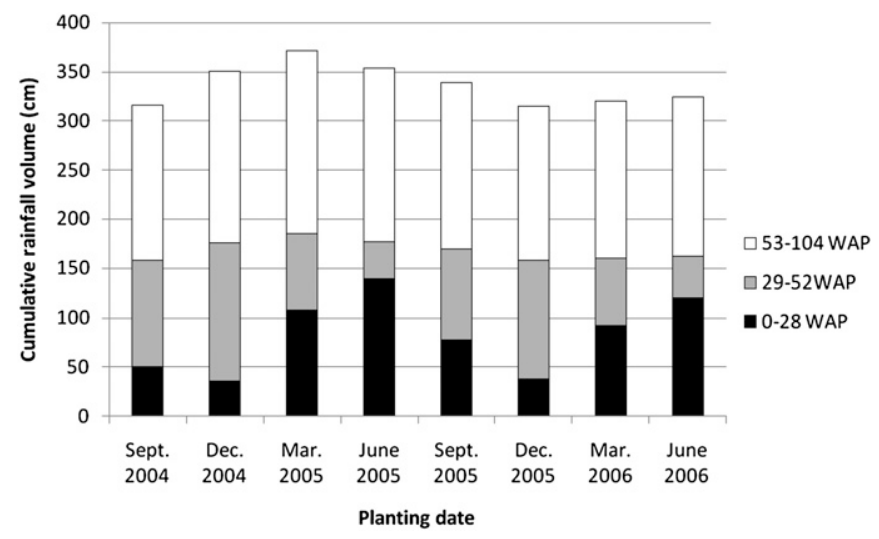

Fig. 1. Cumulative rainfall amounts from 0 to 28, 29 to 52, and 53 to 104 weeks after planting (WAP) as determined by summing the monthly rainfall totals. Shrubs in this 2-year study were planted in Sept. 2004 and 2005, Dec. 2004 and 2005, Mar. 2005 and 2006, and June 2005 and 2006. Monthly rainfall levels were recorded by the Florida Automated Weather Network (FAWN) located within $50 \mathrm{~m}$ $(164.0 \mathrm{ft})$ of the planting site; $1 \mathrm{~cm}=0.3937$ inch. 


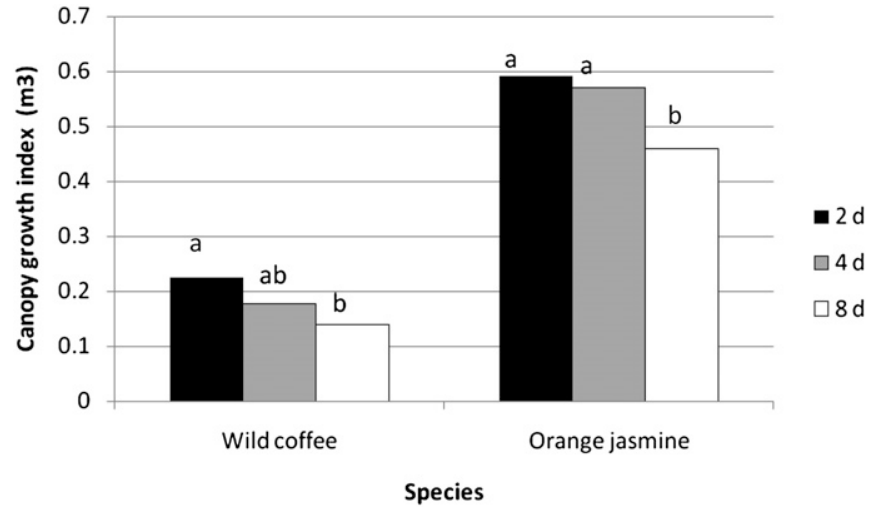

Fig. 2. Canopy growth index (GI) of wild coffee and orange jasmine 28 weeks after planting (WAP). Shrubs were planted in Sept. 2004, Dec. 2004, Mar. 2005, and June 2005 and irrigated every 2, 4, or $8 \mathrm{~d}$ with $3 \mathrm{~L}(0.8 \mathrm{gal})$ of water averaged across four planting dates. Mean separations within a species using Tukey least squares means test at $P=0.05(\mathrm{~N}=24)$. Letters denote significant differences among irrigation frequency treatments for each species (Expt. 1$) ; 1 \mathrm{~m}^{3}=35.3147 \mathrm{ft}^{3}$.

Table 1. Mean root extension to canopy spread ratio, shoot dry weight, and root dry weight at 52 and 104 weeks after planting (WAP) for wild coffee and orange jasmine irrigated every 2,4 , or $8 \mathrm{~d}$ with $3 \mathrm{~L}(0.8 \mathrm{gal})$ of water average across four planting dates in USDA hardiness zone $10 \mathrm{~b}$ (Expt. 1).

\begin{tabular}{|c|c|c|c|c|c|c|}
\hline \multirow{2}{*}{$\begin{array}{l}\text { Irrigation } \\
\text { frequency }(d)\end{array}$} & \multicolumn{2}{|c|}{$\begin{array}{l}\text { Root extension: } \\
\text { canopy spread } \\
\text { (ratio) }\end{array}$} & \multicolumn{2}{|c|}{ Canopy dry wt (g) } & \multicolumn{2}{|c|}{ Root dry wt (g) } \\
\hline & 52 WAP & 104 WAP & 52 WAP & 104 WAP & 52 WAP & $104 \mathrm{WAP}$ \\
\hline & \multicolumn{6}{|c|}{ Wild coffee } \\
\hline 2 & $0.59 \mathrm{a}^{\mathrm{y}}$ & $0.85 \mathrm{a}$ & $237 \mathrm{a}$ & $436 \mathrm{a}$ & $317 \mathrm{a}$ & 506 a \\
\hline 4 & $0.59 \mathrm{a}$ & $0.87 \mathrm{a}$ & $195 \mathrm{ab}$ & $468 \mathrm{a}$ & $318 \mathrm{a}$ & $515 \mathrm{a}$ \\
\hline \multirow[t]{2}{*}{8} & $0.72 \mathrm{a}$ & $0.90 \mathrm{a}$ & $170 \mathrm{~b}$ & 439 a & $273 \mathrm{a}$ & 477 a \\
\hline & \multicolumn{6}{|c|}{ Orange jasmine } \\
\hline 2 & $0.92 \mathrm{a}$ & $1.07 \mathrm{a}$ & $1,041 \mathrm{a}$ & 3,487 a & $729 \mathrm{a}$ & $1,764 \mathrm{a}$ \\
\hline 4 & $1.00 \mathrm{a}$ & $1.13 \mathrm{a}$ & $1,057 \mathrm{a}$ & 3,341 a & $723 \mathrm{a}$ & $1,645 \mathrm{a}$ \\
\hline 8 & $0.92 \mathrm{a}$ & $1.12 \mathrm{a}$ & 897 b & $3,190 \mathrm{a}$ & $698 \mathrm{a}$ & $1,443 \mathrm{a}$ \\
\hline
\end{tabular}

${ }^{\mathrm{z}} 1 \mathrm{~g}=0.0353 \mathrm{oz}$

${ }^{\mathrm{y}}$ Mean separations within columns and species using Tukey least squares means test at $P=0.05(\mathrm{~N}=12)$. Letters denote significant differences among irrigation frequency treatments for each species and planting date.

WAP had a carryover effect on canopy dry weight at 52 WAP. Gilman et al. (1998) reported a similar carryover effect with live oak (Quercus virginiana) in the second year after planting to the landscape, observing that trees grew faster when irrigated frequently for the first 4l WAP than when irrigated infrequently for the first 26 WAP. Several reports confirm that frequently irrigated trees in the landscape have greater shoot growth (e.g., trunk diameter, crown spread, height) than infrequently irrigated plants (Gilman et al., 1998; Marshall and Gilman, 1998; Paine et al., 1992; Stabler and Martin, 2000). Additionally, Scheiber et al. (2007) reported that sweet viburnum (Viburnum odorotissimum) plants grown in a rainout shelter and irrigated every $2 \mathrm{~d}$ had greater leaf area, shoot dry weight, and biomass compared with plants irrigated every $7 \mathrm{~d}$; and 'Variagata' pittosporum (Pittosporum tobira) irrigated every $2 \mathrm{~d}$ had greater leaf area, shoot dry weight, biomass, and final GI compared with plants watered every 4 or $7 \mathrm{~d}$.

Limiting irrigation in Expt. 1 to every $8 \mathrm{~d}$ during the first 28 WAP reduced wild coffee and orange jasmine canopy development but not root development at 52 WAP (Table $1)$. Wild coffee and orange jasmine root extension to canopy spread ratio was not different among the irrigation frequencies at 28,52 , or 104 WAP (Table 1). Root dry weight of both species at 52 and 104 WAP also was not different among the irrigation frequencies (Table 1). Gilman et al. (1996) also reported that 'Burfordii Nana' chinese holly (Ilex cornuta) shoot dry weight and new shoot numbers were greater for plants receiving daily irrigation after transplanting than those receiving periodic irrigation, but there was no difference in total weight of regenerated roots into the landscape soil. It is well established that reduced shoot growth during establishment is often the result of greater plant resources being allocated to root regeneration (Kramer and Kozlowski, 1979). Research suggests that shoot growth is closely related to the availability of water and that shoot growth is inhibited by water stress induced by root pruning or planting into the landscape (Geisler and Ferree, 1984a, 1984b; Watson and Himelick, 1982). Geisler and Ferree (1984b) reported that with the development of new 'Golden Delicious' apple (Malus $\times$ domestica) roots, water relations in the plant improved and shoot growth rates increased.

There are many factors that indicate when a shrub or tree is established in the landscape. One definition for an established tree is the point when shoot growth resumes pretransplant rates (Watson, 1985). Kramer and Kozlowski (1979) stated that tree shoot growth resumes when a natural root to shoot ratio is re-established after planting. Wild coffee had a root extension to canopy spread ratio of 1.0 at $\approx 104 \mathrm{WAP}$, whereas orange jasmine had a ratio of $1.0 \approx 52 \mathrm{WAP}$ (Table 1). We believe this is the reason we did not see differences in GI or canopy dry weight at 104 WAP for either species (Table 1). Further evidence to support that these shrubs resumed canopy growth after 52 WAP is that we observed signs of severe water stress for each planting in Expt. 1 between 28 and 52 WAP, which required that we apply $3 \mathrm{~L}$ of supplementalirrigation byhand. However, after $52 \mathrm{WAP}$, none of the shrubs planted in Expt. 1 showed signs of water stress or required supplemental irrigation.

When planting trees into welldrained sandy soils as found in much of Florida and other parts of the country, it has been suggested that trees require near daily irrigation after transplanting to maintain maximum rates of root regeneration (Beeson 
and Gilman, 1992). Harris and Gilman (1993) reported that 'East Palatka' holly (Ilex ×attenuata) plants from plastic containers irrigated daily had greater root dry weight, root volume, and root extension than plants irrigated periodically. As a result of the poor performance of plants irrigated every $8 \mathrm{~d}$ in Expt. 1 and literature suggesting the benefits of daily irrigation, the 8-d irrigation frequency was replaced in Expt. 2 with the every $1-d$ (daily) frequency.

In Expt. 2, there was no difference at 28,52 , or 104 WAP in orange jasmine or copperleaf GI, root extension to canopy spread ratio, canopy dry weight, or root dry weight among the irrigation frequencies $(1,2$, or $4 \mathrm{~d}$ ) (data not shown). This supports our results from Expt. 1 with orange jasmine in which there was no difference in growth between the 2- and 4 -d irrigation treatments. It also appears that there was no added benefit to irrigating every $\mathrm{l} d$ versus every 2 or $4 \mathrm{~d}$ for either orange jasmine or copperleaf. Although Montague et al. (2007) reported that shoot dry weight of 'Victor' crapemyrtle (Lagerstroemia indica), spirarea (Spiraea $\times$ vanhouttei), and photinia was greater for plants irrigated with high $\left(100 \%\right.$ reference $\left.\mathrm{ET}_{\mathrm{O}}=6875 \mathrm{~L}\right)$ and medium $\left(75 \%\right.$ reference $\mathrm{ET}_{\mathrm{O}}=5156$ L) irrigation than with low irrigation $\left(50 \%\right.$ reference $\left.\mathrm{ET}_{\mathrm{O}}=3438 \mathrm{~L}\right)$, they suggest that these species should be irrigated with the $75 \% \mathrm{ET}_{\mathrm{O}}$ and mulched to conserve over $1700 \mathrm{~L}$ of water. They also reported that using organic mulch and irrigating plants at $50 \%$ reference $\mathrm{ET}_{\mathrm{O}}$ produced growth and aesthetic qualities that would be acceptable in landscape situations and would save $\approx 3400$ L of water. Results from our two experiments suggest that irrigating plants every $4 \mathrm{~d}$ during the first 28 weeks will produce acceptable plants in the landscape and save over $390 \mathrm{~L}$ of water compared with irrigating plants every $\mathrm{l} \mathrm{d}$ and save over $90 \mathrm{~L}$ of water compared with irrigating every $2 \mathrm{~d}$.

\section{Conclusions}

Wild coffee, copperleaf, and orange jasmine grown under conditions similar to these experiments should be irrigated no less frequently than every $4 \mathrm{~d}$ with $3 \mathrm{~L}$ of water for $\approx 28$ weeks for optimum canopy growth and development. There appears to be no benefit (e.g., increased growth) to increasing irrigation frequency to either every 1 or 2 d. After 28 weeks in the ground with irrigation, in years receiving a normal rainfall pattern, rain fall events should be sufficient to keep these shrubs alive and growing and irrigation can be ended. Supplemental irrigation should be applied, after 28 weeks irrigation has been discontinued, for 2 years only when shrubs exhibit signs of severe water stress (e.g., wilting, leaf drop, or yellowing or browning leaves) and when rainfall is less than $6 \mathrm{~mm}$ in any 24 -h period consecutively for $30 \mathrm{~d}$.

\section{Literature cited}

Barnett, D. 1986. Root growth and water use by newly transplanted woody landscape plants. Public Garden 1:23-25.

Beeson, R.C., Jr. and E.F. Gilman. 1992. Diurnal water stress during landscape establishment of slash pine differences among three production methods. J. Arboriculture 18:281-287.

Broschat, T.K. and A.W. Meerow. 1996. Betrock's reference guide to Florida landscape plants. Betrock Information Systems, Hollywood, FL.

Cathey, H.M. 1990. The United States National Aboretum, USDA plant hardiness zone map, south-east US. 29 Jan. 2009. <http://www.usna.usda.gov/Ha rdzonehzm-sel.html>.

Costello, L. and J.L. Paul. 1975. Moisture relations in transplanted container plants. HortScience 10:371-372.

Fitzpatrick, G. and D. Burch. 1986. Interactive effects of nursery and landscape irrigation rates on growth and establishment of two landscape ornamentals. Proc. Florida State Hort. Soc. 99:159-161.

Geisler, D. and D.C. Ferree. 1984a. Response of plants to root pruning. Hort. Rev. (Amer. Soc. Hort. Sci.) 6:155188.

Geisler, D. and D.C. Ferree. 1984b. The influence of root pruning on water relations, net photosynthesis and growth of young 'Golden Delicious' apple trees. J. Amer. Soc. Hort. Sci. 109:827-831.

Gilman, E.F. 1996. Betrock's Florida plant guide. Betrock Information Systems, Hollywood, FL.

Gilman, E.F., R.J. Black, and B. Dehgan. 1998. Irrigation volume and frequency and tree size affect establishment rate. J. Arboriculture 24:1-9.
Gilman, E.F., A.L. Shober, K.A. Moore, C. Wiese, and M. Paz. 2009. Planting shrubs in Florida landscapes. Univ. Florida, Inst. Food Agr. Sci. EP390.

Gilman, E.F., T.H. Yeager, and D. Weigle. 1996. Fertilizer, irrigation and root ball slicing affects burford holly growth after planting. J. Environ. Hort. 14:105110.

Harris, J.R. and E.F. Gilman. 1993. Production method affects growth and posttransplant establishment of 'East Palatka' holly. J. Amer. Soc. Hort. Sci. 118:194200 .

Kramer, P.J. and T.T. Kozlowski. 1979. Physiology of woody plants. Academic Press, New York, NY.

Marshall, M.D. and E.F. Gilman. 1998. Effects of nursery container type on root growth and landscape plant establishment of Acer rubrum L. J. Environ. Hort. 16:55-59.

Montague, T., R. Kjelgren, and L. Rupp. 2000. Gas exchange and growth of two transplanted, field-grown tree species in an arid climate. HortScience 35:736738 .

Montague, T., C. McKenney, M. Maurer, and B. Winn. 2007. Influence of irrigation volume and mulch on establishment of select shrub species. Arboriculture Urban For. 33:202-209.

National Oceanic and Atmospheric Administration. 2002. Monthly station normals of temperature, precipitation, and heating and cooling degree days 1971-2000:08-Florida, Ashville. 24 Mar. 2009. <http://cdo.ncdc.noaa.gov/ climatenormals/clim81/FLnorm.pdf $>$.

Paine, T.D., C.C. Hanlon, D.R. Pittenger, D.M. Ferrin, and M.K. Malinoski. 1992. Consequences of water and nitrogen management on growth and aesthetic quality of drought-tolerant woody landscape plants. J. Environ. Hort. 10:94-99.

Renquist, R. 1987. Evapotranspiration calculations for young peach trees and growth responses to irrigation amount and frequency. HortScience 22:221223.

Scheiber, S.M., E.F. Gilman, M. Paz, and K.A. Moore. 2007. Irrigation affects landscape establishment of burford holly, pittosporum, and sweet viburnum. HortScience 42:344-348.

South Florida Water Management District. 2008. Watering restrictions. 22 Dec. 2008. <http://sfwmd.gov/watershortage >.

Southwest Florida Water Management District. 2008. Water restrictions. 22 Dec. 2008. <http://www.swfwmd.state. fl.us/conservation/restrictions/>. 
St. Johns River Water Management District. 2008. Drought information and irrigation rule. 22 Dec. 2008. <http:// sjr.state.fl.us/irrigationrule/index.html>.

Stabler, L.B. and C.A. Martin. 2000. Irrigation regimens differentially affect growth and water use efficiency of two southwest landscape plants. J. Environ. Hort. 18:66-70.
Trenholm, L.E., E.F. Gilman, G.W Knox, and R.J. Black. 2002. Fertilization and irrigation needs for Florida lawns and landscapes. Univ. Florida, Inst. Food Agr. Sci. ENH860.

University of Florida. 2008. Florida Automated Weather Network, report generator. 10 Dec. 2008. <http://fawn.ifas. ufl.edu/data/reports $/>$.
Watson, G.W. 1985. Tree size affects root regenerations and top growth after transplanting. J. Arboriculture 11:3740 .

Watson, G.W. and E.B. Himelick. 1982. Root distribution of nursery trees and its relationship to transplanting success. J. Arboriculture 8:225-229. 